\title{
Hubungan Sikap Ibu Tentang Pemberian Makanan Bayi Dan Anak (PMBA) Dengan Status Gizi Bayi Bawah Dua Tahun (Baduta)
}

Fatimah Sari \& Evy Ernawati

\section{Abstract}

Background: The growth and development in infants is very rapidly. The growth and development can be realized optimally when on the gold period, babies obtain the appropriate nutritional intake of Breast Milk is recommended as one of the exclusive source of nutrition in the first 6 months. Nutrition deficiency is suspected due to a lack of understanding of parents or proper nutritious food to the influence of advertising. They want to break the cycle of malnutrition that causes children short.

Objective: This research aims to know the relationship of attitude about the feeding of infants and children (PMBA) with the nutritional status of infants under two years (BADUTA).

Method: This type of research is descriptive analytic with cross-sectional approach. Research subjects who had a Mother Baduta in the village of Pandes Wedi Klaten Regency in Central Java. The way of determining the sample by the total sampling techniques. Instrument research using questionnaires conducted test validity and reabilitas. Analysis of data for the purpose of hypothesis testing using statistical tests Spearman Rho.

Results: the attitude of Mothers in feeding on baduta with the results of positive mothers attitude that is as much as $100 \%$. Baduta good nutritional status i.e. as many as 20 people $(66.67 \%)$, nutritional Status of less baduta that is as much as 10 (33.33\%). The results obtained bivariat relationship attitude mother with nutritional Status Baduta the value of $p=0,062$ because $>0.05 p(p=0,062>0.05)$ then it can be stated there was no relationship between maternal attitudes towards nutritional status of infants under two years of age.

Conclusion: there is no relationship with the mother's nutritional status attitude baduta with a value of $p=0,062$

Keywords: attitude, nutritional status

Afiliasi Penulis

STIKes Guna Bangsa Yogyakarta

Korespondensi kepada

F. Sari

fatimah_sari@gunabangsa.ac.id 


\section{Intisari}

Latar Belakang: Pertumbuhan dan perkembangan pada bayi sangat pesat. Pertumbuhan dan perkembangan tersebut dapat diwujudkan secara optimal apabila pada masa periode emas tersebut, bayi memperoleh asupan gizi yang sesuai. ASI dianjurkan sebagai salah satu sumber eksklusif gizi dalam 6 bulan pertama. Kurang gizi diduga disebabkan kurangnya pemahaman orang tua makanan bergizi yang tepat atau pengaruh iklan. Mereka ingin memutus siklus gizi buruk yang menyebabkan anak pendek.

Tujuan: Penelitian ini bertujuan untuk mengetahui hubungan sikap tentang pemberian makanan bayi dan anak (PMBA) dengan status gizi bayi bawah dua tahun (BADUTA).

Metode: Jenis penelitian ini adalah deskriptif analitik dengan pendekatan cross-sectional. Subyek penelitian Ibu yang mempunyai Baduta di Desa Pandes Wedi Kabupaten Klaten Jawa Tengah. Cara penentuan sampel dengan teknik total sampling. Instrumen penelitian menggunakan kuesioner yang dilakukan uji validitas dan reabilitas. Analisis data untuk keperluan pengujian hipotesis menggunakan uji statistik Spearman Rho.

Hasil: sikap Ibu dalam pemberian makan pada baduta dengan hasil sikap ibu positif yaitu sebanyak 100 $\%$. Status gizi baduta baik yaitu sebanyak 20 orang $(66,67 \%)$, Status gizi baduta kurang yaitu sebanyak 10 (33,33\%). Hasil diperoleh bivariat hubungan sikap Ibu dengan Status Gizi Baduta nilai $p=0,062$ oleh karena $p>0,05(p=0,062>0,05)$ maka dapat dinyatakan tidak terdapat hubungan antara sikap ibu terhadap status gizi bayi dibawah dua tahun.

Kesimpulan: Tidak terdapat hubungan sikap ibu dengan status gizi baduta dengan nilai $p=0,062$

Kata kunci: Sikap ibu, status gizi

\section{Pendahuluan}

Pertumbuhan dan perkembangan pada bayi sangat pesat. Pertumbuhan dan perkembangan tersebut dapat diwujudkan secara optimal apabila pada masa periode emas tersebut, bayi memperoleh asupan gizi yang sesuai. Paradigma pertama 1000 hari kehidupan merupakan periode dari konsepsi dan memberi kesempatan dalam menyelamatkan kehidupan dan masa depan anak. ASI dianjurkan sebagai salah satu sumber eksklusif gizi dalam 6 bulan pertama (Solomons dan Vossenaar, 2013). Pada Negara dengan penghasilan rendah pertumbuhan pada bayi dan balita terjadi kegagalan dimulai dari sejak lahir sampai berumur 3 bulan. Salah satu dari kegagalan dalam praktik pemberian makananan yang salah pada bayi dan anak adalah terjadinya stunting (bayi pendek) (Solomons dan Vossenaar, 2013). Hasil Survai Demografi dan Kesehatan (SDKI) tahun 2012 menunjukkan Angka kematian bayi di DIY mempunyai angka yang relatif lebih tinggi sebesar 25 per 1.000 kelahiran hidup, sedangkan angka kematian balita di DIY menurut SDKI tahun 2012 sebesar 30 per 1.000 kelahiran hidup terendah kedua secara Nasional setelah Provinsi Riau. Perwakilan United Nations for Children Fund (UNICEF) Indonesia dan Uni Eropa mendapati adanya 19 bayi di bawah dua tahun (baduta) yang mengalami stunting atau pendek dilihat dari standar antopomeri WHO dan seorang bayi yang mengalami gizi buruk. Data tersebut diperoleh dari total 140 baduta yang ada di Desa Pandes Kecamatan Wedi Kabupaten Klaten (WHO, 2014). Di Pandes terdapat 140 baduta (bayi di bawah dua tahun) pada waktu dikumpulkan ada 107 baduta yang hadir. Dari yang baduta yang hadir, ada 19 bayi yang pendek menurut antropometri WHO. Satu bayi berusia 20 bulan mengalami gizi buruk karena beratnya hanya 7,1 kg. Kurang gizi diduga disebabkan kurangnya pemahaman orang tua makanan bergizi yang tepat atau pengaruh iklan. Mereka ingin memutus siklus gizi buruk yang menyebabkan anak pendek. IMD (inisiasi Menyusui Dini) dan ASI eksklusif selama 6 bulan diberikan di Desa Pandes Wedi akan tetapi kegagalan yang 
terjadi saat pemberian makanan pendamping ASI yang kurang tepat, karena tergoda dengan iklan yang ada di Televisi, Koran, majalah dan Desa Pandes ingin memperbaiki lewat PMBA.

\section{Metode}

Penelitian ini menggunakan metode deskriptif analitik. Pendekatan yang digunakan adalah cross sectional. Jenis penelitian ini adalah deskriptif analitik dengan pendekatan cross-sectional. Instrumen penelitian menggunakan kuesioner yang dilakukan uji validitas dan reabilitas. Analisis data untuk keperluan pengujian hipotesis menggunakan uji statistik Spearman Rho. Uji korelasi Spearman Rho (tata jenjang) dengan rumus sebagai berikut (Arikunto, 2010):

$$
r h o_{x y}=\frac{6 \Sigma D^{2}}{N\left(N^{2}-1\right)}
$$

\footnotetext{
Keterangan:

rho $_{x y}$ : koefesiensi korelasi antara variabel $x$ dan $y$

$\mathrm{D}$ : Difference (beda antar jenjang setiap subjek)

$\mathrm{N}$ : Jumlah responden

$\mathrm{X} \quad$ : Jumlah skor tiap butir

$Y \quad$ : skor total tiap butir
}

Untuk mengetahui adanya hubungan antara sikap ibu tentang Pemberian makanan tambahan pada bayi dan anak (PMBA) dengan status gizi baduta jika $p$ hitung $<0,05$ dengan taraf signifikansi $5 \%$, maka Ho ditolak dan Ha diterima. Artinya ada hubungan antara tingkat pengetahuan tentang pemberian makanan bayi dan anak (PMBA) dengan status gizi bayi bawah dua tahun. Jika $p$ hitung $>$ 0,05 dengan taraf signifikansi 5\%, maka Ho diterima dan $\mathrm{Ha}$ ditolak. Artinya tidak ada hubungan antara sikap ibu tentang pemberian makanan bayi dan anak (PMBA) dengan status gizi bayi bawah dua tahun.

Populasi dari penelitian ini adalah seluruh Ibu yang mempunyai baduta di Desa Pandes Wedi

\begin{tabular}{ccc}
\multicolumn{2}{c}{ Tabel 1 | Sikap lbu dalam pemberian makan pada baduta } \\
No & Sikap lbu & Jumlah \\
\hline 1 & Positif & $30(100 \%)$ \\
2 & Negatif & $0(0 \%)$ \\
Jumlah & & $30(100 \%)$
\end{tabular}

Kabupatan Klaten Jawa Tengah. Tekhnik sampling yang dipakai dalam penelitian ini adalah dengan random adalah 30 subjek dari lbu yang mempunyai Baduta di Desa Pandes Wedi Kabupaten Klaten Jawa Tengah.

\section{Hasil \& Pembahasan}

\section{Analisis univariat}

Analisis ini untuk menjelaskan atau menggambarkan karakteristik setiap variabel penelitian yang menghasilkan distribusi frekuensi dan persentase dari setiap variabel, variabel dalam penelitian ini meliputi sikap ibu dalam pemberian makan pada bawah dua tahun dan Status gizi bayi dibawah dua tahun.

\section{Sikap ibu dalam pemberian makan pada baduta}

Berdasarkan penelitian diperoleh data tentang sikap Ibu dalam pemberian makan pada baduta dengan hasil rata- rata sikap Ibu positif dalam pemberian makan pada baduta.

Berdasarkan tabel 1. Menunjukkan bahwa sikap ibu dalam pemberian makan pada baduta $100 \%$ positif.

\section{Status gizi bayi di bawah dua tahun}

Berdasarkan penelitian diperoleh data tentang status gizi bayi dibawah dua tahun dengan hasil rata- rata status gizi baduta Baik.

Berdasarkan tabel 2. Menunjukkan bahwa status gizi baduta baik yaitu sebanyak $66,67 \%$.

\section{Analisis bivariat}

Berdasarkan analisis bivariat (tabel 3) hubungan sikap Ibu dengan status gizi baduta membandingkan nilai signifikansi Sig. (2-tailed) atau probabilitas (p) dengan taraf signifikansi $5 \%(0,05)$. Ketentuan signifikan apabila nilai $p<0,05$. Diperoleh nilai $p=0,062$ oleh karena $p>0,05(0,062>0,05)$ maka dapat dinyatakan tidak terdapat hubungan antara sikap orang tua terhadap status gizi bayi dibawah dua tahun.

Tabel 2 | Status gizi bayi di bawah dua tahun

\begin{tabular}{ccc} 
No & Status Gizi & Jumlah \\
\hline 1 & Baik & $20(66,67 \%)$ \\
2 & Kurang & $10(33,33 \%)$ \\
Jumlah & & $30(100 \%)$
\end{tabular}


Tabel 3 | Hubungan Sikap Ibu dengan Status Gizi baduta

\begin{tabular}{|c|c|c|c|c|}
\hline & & & Sikap & Status Gizi \\
\hline \multirow{6}{*}{$\begin{array}{c}\text { Spearman's } \\
\text { Rho }\end{array}$} & \multirow{3}{*}{ Sikap } & Correlation & 1,000 & 0,345 \\
\hline & & $\begin{array}{l}\text { Coefficient Sig. } \\
\text { (2-tailed) }\end{array}$ & & 0,062 \\
\hline & & $\mathrm{N}$ & 30 & 30 \\
\hline & \multirow{3}{*}{ Status Gizi } & Correlation & 0,345 & 1,000 \\
\hline & & $\begin{array}{l}\text { Coefficient Sig. } \\
\text { (2-tailed) }\end{array}$ & 0,062 & \\
\hline & & $\mathrm{N}$ & 30 & 30 \\
\hline
\end{tabular}

Status gizi adalah suatu ukuran mengenai akibat konsusmsi yang dapat dilihat dari makanan yang dikonsumsi dan penggunaan zat-zat gizi di dalam tubuh. Status gizi dibagi menjadi 4 kategori, yaitu gizi buruk,gizi kurang, gizi normal,dan gizi lebih (Almatsier,2005). Status gizi adalah gambaran kondisi fisik seorang sebagai refleksi dari keseimbangan energi yang masuk dan dikeluarkan oleh tubuh. Status gizi seorang dapat dinilai dengan mengukur antropometri), yaitu berat badan, tinggi badan, lingkar lengan atas, serta tebal lemak dibawah kulit (Supariasa,2012). Hasil yang diperoleh dalam penelitian ini tidak menunjukkan hubungan antara sikap ibu tentang pemberian makanan tambahan pada bayi dan anak (PMBA) dengan status gizi baduta secara langsung. Hal ini tidak sesuai dengan supariasa (2012) bahwa Pendidikan merupakan salah satu factor eksternal yang mempengaruhi status gizi. Pendidikan merupakan suatu proses merubah pengetahuan, sikap dan perilaku orang tua atau masyarakat untuk mewujudkan dengan status gizi yang baik. Pengetahuan ibu yang cukup baik mengenai pemenuhan gizi balita merupakan dasar terbentuknya sikap dan akhirnya membentuk perilaku (Azwar, 2007). Anak usia 1-3 tahun merupakan konsumen pasif yang menerima makanan yang disediakan oleh ibunya (Uripi, 2004). Kurang gizi akan berpengaruh pada perkembangan fisik dan mental. Pada penelitian ini terlihat adanya kecenderungan bahwa sikap ibu yang baik tidak menjamin status gizi baduta juga baik. Hal ini tidak terlepas dari faktor-faktor lain yang mempengaruhi status gizi pada bayi seperti faktor eksternal (Pendapatan, Pendidikan, Pekerjaan, Budaya) dan factor internal (Usia ibu, Kondisi fisik, Infeksi).

\section{Kesimpulan}

Berdasarkan hasil analisis dan pembahasan yang telah diuraikan sebelumnya, dapat ditarik kesimpulan bahwa ibu baduta yang bersikap positif yaitu $100 \%$, status gizi pada baduta sebagian besar adalah baik yaitu sebesar $66,66 \%$ dan tidak terdapat hubungan tingkat pengetahuan dengan status gizi baduta dengan nilai $p=0,062$.

\section{Bibliografi}

1. Solomons \& Vosesaar, (2013). Nutrient density in complementary feeding of infants and toddlers.

2. European Journal of Clinical Nutrition (2013) $67,501-$ 506;doi:10.1038/ejcn.2013.46; published online 27 February 2013.

3. Profil Kesehatan Kabupaten Klaten, (2013). Dinas Kesehatan Kabupaten Klaten.

4. Arikunto,S, (2010). Prosedur Penelitian: Suatu Pendekatan Praktek. Jakarta : Rineka Cipta.

5. Almatsier S. 2001. Prinsip dasar ilmu gizi.Jakarta :Gramedia pustaka utama

6. Supariasa I, Bakri B, Fajar I. (2002). Penilaian status gizi . EGC 